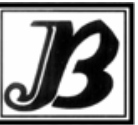

J. bio-sci. 18: 108-115, 2010

ISSN 1023-8654

http://www.banglajol.info/index.php/JBS/index

\title{
PURIFICATION, CHARACTERIZATION AND EFFECT OF PHYSICO-CHEMICAL AGENTS ON THE STABILITY OF $\beta$-GALACTOSIDASE FROM BETEL LEAVES
}

\author{
M S Shovon, S C D Sharma, N Roy* \\ Department of Biochemistry \& Molecular Biology, University of Rajshahi, Rajshahi-6205, Bangladesh
}

\begin{abstract}
Context: $\beta$-galactosidase are present in a wide variety of organisms including plants, animals and microorganisms. Exploration of this enzyme from plant source will help to address the problems faced in the food and allied industries that look for enzymes with novel properties.

Objectives: The aim of this study is to explore the purification, characterization and analysis of $\beta$-galactosidase from betel leaves.

Materials and Methods: Aomal Bangla variety of betel leaf (Piper betle Linn.) was collected from betel vine. The column chromatographic method was done at $4^{\circ} \mathrm{C}$ using conventional method. The protein concentration was determined by UV-spectrophotometer at $280 \mathrm{~nm}$. The activities of $\beta$-galactosidase were done by spectrophotometric method. All other reagents used in the study were of analytical grade. Unless specified, all the experimental conditions are maintained at $4^{\circ} \mathrm{C}$.

Results: After extraction of $\beta$-galactosidase from betel leaves, the crude enzyme was applied to DEAE-cellulose chromatography with sodium phosphate buffer ( $\mathrm{pH}$ 7.0). The active fraction from DEAE-column chromatography was dialyzed with buffer and applied to CM-cellulose chromatography. The $\beta$-galactosidase activity from CM-cellulose chromatography was loaded to Sephadex G-75 Gel filtration chromatography. In this column, the enzyme $\beta$ galactosidase was eluted in a single peak. The homogeneity of purity was checked by disc gel electrophoresis and a single band was obtained. The optimum pH of $\beta$-GS-I, $\beta$-GS-II and $\beta$-GS-III were $3.5,3.8$ and 4.2 , respectively. The optimum temperatures of the enzymes were 53,51 and $56^{\circ} \mathrm{C}$, respectively.

Conclusion: The results obtained in this study suggest that three $\beta$-galactosidases namely $\beta$-GS-I, $\beta$-GS-II and $\beta$ GS-III were purified from betel leaves. This is the first report of purification and characterization of $\beta$-galactosidase from betel leaves.
\end{abstract}

Keywords: Betel leaves, $\beta$-galactosidase, MW, characterisation, stability.

\section{Introduction}

The enzyme $\beta$-galactosidase (EC 3.2.1.23) catalyzes the hydrolysis of lactose to glucose and galactose. This enzyme is industrially important because it can be used to avoid lactose crystallization in sweetened, condensed and frozen dairy products such as ice cream and condensed milk and solve problems associated with whey utilization and disposal (Dagbagli and Goksungur 2008). In addition $\beta$-galactosidase is used to avoid the problems of lactose intolerance by individuals who are deficient in lactose (Artolozaga et al. 1998).

$\beta$-galactosidase are present in a wide variety of organisms including plants, animals and microorganisms, and are known to catalyze both hydrolytic and transglycosylation reactions (Asraf and Gunasekaran 2010). They are widely distributed in various plant tissues, including developing fruits (Bartley 1974, Burns1990, Corchete and Guerra 1987, Dey and Campillo 1984, Gross et al.1986, Konno et al. 1986). Studies on apple (Bartley 1974) and hot pepper (Gross et al.1986) have indicated remarkable increases in the activity of $\beta$ galactosidase during ripening. One $\beta$-galactosidase isozyme in tomato that increases its activity during ripening has exhibited the ability to hydrolyze galactose-rich polysaccharide in vitro from its cell walls (Pressey 1983). These findings suggest possible involvement of $\beta$-galactosidases in modification of cell wall components during the ripening of fruits. Commercia $\beta$-galactosidase are produced from yeasts such as

* Corresponding author 
Kluyveromyces lactis and K. marxianus, and moulds such as Aspergillus niger and A. oryzae (Shaikh et al. 1997, Santos et al. 1998).

Betel leaf (Piper betle Linn.) is an evergreen perennial, with glossy heart-shaped leaves and white catkin inflorescence, and grows to a height of about 1 metre. The Betel plant originated in Malaysia and now grows in Bangladesh, India, Indonesia and Sri Lanka. Betel leaves are stimulant, digestive, carminative, antiflatulent, anti-inflammatory, invigorating, anti phlegmatic, pain reliever. In fact, this edible leaf has achieved an esteemed position in the human society right from the dawn of civilization, particularly in the countries like Bangladesh, Burma, China, India, Indonesia, Malaysia, Nepal, Pakistan, Philippines, South Africa, Sri Lanka, Thailand etc. (Sharma et al. 1996), where leaves are traditionally used for chewing in their natural raw condition along with many other ingredients like sliced areca nut, slaked lime, coriander, aniseed, clove, cardamom, sweetener, coconut scrapings, ashes of diamond, pearl, gold and silver (Ayurvedic preparations), jelly, pepper mint, flavouring agent, fruit pulp etc. (CSIR 1969). An analysis of the betel leaf shows it to consist of moisture 85.4 per cent, protein 3.1 per cent, fat 0.8 per cent, minerals 2.3 per cent, fiber 2.3 per cent and carbohydrates 6.1 per cent per 100 grams (Guha 2006).

The present paper includes the purification, characterization and effect of physico-chemical agents on the stability of $\beta$-galactosidases from betel leaves at mature stage.

\section{Materials and Methods}

Preparation of crude enzyme extract: The betel leaves (Aomal Bangla variety) were collected from Mohanpur upozila of Rajshahi. Fresh leaves (100 $\mathrm{g}$ in weigh) cut into small pieces and grinded in a mortar and pestle with $25 \mathrm{ml}$ of cold $50 \mathrm{mM}$ phosphate buffer, $\mathrm{pH} 7.4$ and finally crushed into paste using homogenizer. The temperature was maintained at $4^{\circ} \mathrm{C}$ by putting ice in the outer chamber of homogenizer. The suspension was then filtered through double layers muslin cloth in the cool chamber. The filtrate collected was further clarified by centrifugation at $10000 \mathrm{~g}$ for $15 \mathrm{~min}$ at $4^{\circ} \mathrm{C}$. The clear supernatant was concentrated about $1 / 8^{\text {th }}$ of the original volume by commercial sucrose at $4^{\circ} \mathrm{C}$. Then it was dialyzed against $50 \mathrm{mM}$ phosphate buffer, $\mathrm{pH} 7.4$ for $24 \mathrm{~h}$ at $4^{\circ} \mathrm{C}$. It was again centrifuged at $7000 \mathrm{~g}$ for $15 \mathrm{~min}$, to remove insoluble material and the clear supernatant was used as crude enzyme extract.

Column chromatographies: The crude enzyme extract was loaded onto the DEAE-cellulose column (Sigma Chemical Co. USA), which was previously equilibrated with $50 \mathrm{mM}$ phosphate buffer, $\mathrm{pH} 7.4$ at $4^{\circ} \mathrm{C}$. The protein was eluted from the column with the same buffer by stepwise elution containing increasing concentration of $\mathrm{NaCl}$. Absorbance at $280 \mathrm{~nm}$, protein concentration and $\beta$-galactosidase activity of each fraction were measured. The $\beta$-galactosidase containing fraction obtained from DEAE-cellulose was applied to CM-cellulose column (Sigma Chemical Co. USA) after dialysis against $0.1 \mathrm{M}$ sodium-acetate buffer, $\mathrm{pH}$ 5.2. The protein was eluted from the column with the same buffer by stepwise elution containing different concentration of $\mathrm{NaCl}$. Absorbance at $280 \mathrm{~nm}$, protein concentration and $\beta$-galactosidase activity of each fraction were measured. The impure enzyme active fraction obtained from $\mathrm{CM}$-cellulose was applied on Sephadex G-75 column (Sigma Chemical Co. USA) after dialysis against 0.1 M Na-acetate buffer, pH 5.2. The protein was eluted from the column by the same buffer. Absorbance at $280 \mathrm{~nm}$, protein concentration and enzyme activity of each fraction were measured.

Polyacrylamide disc gel electrophoresis: The purity of the enzyme containing fractions was detected by polyacrylamide disc gel electrophoresis at room temperature on $7.5 \%$ gel, pH 8.3 as described by Ornstein (1964).

Assay of $\beta$-galactosidase activity: $\beta$-galactosidase activity was assayed following the modified method as described by Lazan et al. (1993) using Methyl $\beta$-D-galactopyranoside as substrate. Amount of reducing sugar released was estimated by dinitrosalicyclic acid (Miller 1972). The $\beta$-galactosidase activity was 
measured by estimating the amount of reducing sugar released from methyl- $\beta$-D-galactopyranoside. One unit of $\beta$-galactosidase activity was defined as the amount of enzyme that catalyzed the liberation of $1 \mathrm{mg}$ of galactose in $15 \mathrm{~min}$ at $37^{\circ} \mathrm{C}$ and the amount of galactose released was calculated from the standard curve prepared with galactose. The concentration of protein was determined following the method of Lowry et al. (1951) using BSA as standard.

Determination of molecular weight: The molecular weight of $\beta$-galactosidase was determined by gel filtration on Sephadex G-150 as described by Andrews (1964). Catalase, $\beta$-galactosidase, carbonic anhydrase and lysozyme were used as marker proteins. The molecular weight of the subunits of $\beta$-galactosidases were determined by SDS-polyacrylamide gel electrophoresis as described by Weber and Osborn (1969).

Estimation of total sugar, optimum $\mathrm{pH}$ and temperature: Total sugar contents of $\beta$-galactosidases were estimated by Phenol sulphuric acid method (Dubois 1956). The activities of $\beta$-galactosidases against Methyl$\beta$-D-galactopyranoside as substrate was assayed using $0.1 \mathrm{M}$ buffers of different $\mathrm{pH}$ values (range, $2-10$ ) at $37^{\circ} \mathrm{C}$ following the procedure as described above. The activities of the $\beta$-galactosidases were measured at different temperature $\left(10-90^{\circ} \mathrm{C}\right)$ using sodium citrate buffer of $\mathrm{pH}, 3.6-4.2$. At first the enzyme solutions were incubated at different temperature for $15 \mathrm{~min}$ and then the activities of the enzyme solutions were measured following the procedure as described above.

Treatment with urea, acetic acid, calcium and various salts: To the $\beta$-galactosidases solution (in sodium citrate buffer of $\mathrm{pH} 3.6-4.2)$ of $0.5 \mathrm{ml}(0.25-0.30 \mathrm{mg} / \mathrm{ml}$ ), were added urea, calcium, acetic acid (all from BDH, England) and various salts at different concentrations and incubated for $10 \mathrm{~min}$ at $20^{\circ} \mathrm{C}$. The mixtures were again incubated with the substrate for $15 \mathrm{~min}$ at $37^{\circ} \mathrm{C}$ and the enzyme activity was assayed.

\section{Results}

lon exchange chromatography on DEAE-cellulose of crude enzyme extract prepared from fresh betel leaves are presented in Fig 1. It was found that the proteins of crude enzyme extract were eluted from the column in five fractions. The major fraction, F-1 was eluted from the column by the buffer only, while the other four minor fractions namely F-2, F-3, F-4 and F-5 were eluted from the column by the buffer containing $0.1,0.2$, 0.25 and $0.3 \mathrm{M} \mathrm{NaCl}$, respectively. It was also found that the major fraction $\mathrm{F}-1$ contained only the $\beta$ galactosidase activity. The area as indicated by solid bar of F-1 fraction was pooled separately and purified further by ion-exchange chromatography on CM-cellulose. The enzyme active fraction F-1, obtained after DEAE-cellulose chromatography, was dialyzed against $0.1 \mathrm{M}$ sodium acetate buffer, pH 5.2 for $24 \mathrm{~h}$ and applied to CM-cellulose column previously equilibrated with the same buffer at $4^{\circ} \mathrm{C}$.

As shown in Fig. 2, the components of the fraction F-1, were separated from the column in four fractions. Of those fractions, F-1a was eluted from the column by the buffer only, while the other fractions, i.e. F-1b, F-1c and $\mathrm{F}-1 \mathrm{~d}$ were eluted from the column by the buffer containing $0.1 \mathrm{M}, 0.2 \mathrm{M}$, and $0.3 \mathrm{M} \mathrm{NaCl}$ respectively. It was found that only the fractions F-1a and F-1c contained the $\beta$-galactosidase activity. The homogeneity of these fractions was checked by polyacrylamide disc gel electrophoresis. Only F-1c fraction contained pure enzyme as it gave single band on the gel, while the components of F-1a gave more than one band. So F-1a fraction was subjected to gel filtration for further purification. The fraction F-1a obtained from CM-cellulose chromatography was dialyzed against $0.1 \mathrm{M}$ sodium acetate buffer, $\mathrm{pH} 5.2$ for overnight, concentrated with sucrose and applied to Sephadex G-75 column at $4^{\circ} \mathrm{C}$ previously equilibrated with the same buffer. As shown in Fig. 3, the fraction F-1a was separated into two fractions, F-1a' and F-1a" and it was also found that both the fractions contained $\beta$-galactosidase activity. The area as indicated by solid bar of F-1a' and F-1a" were pooled separately and their homogeneity were determined by polyacrylamide gel electrophoresis. Both the fractions might be contained pure enzyme as they gave single band on polyacrylamide gel electrophoresis (Fig. 4).The pure $\beta$-galactosidase containing fractions i.e. F-1a', F-1a" and F-1c were named as $\beta$-galactosidase-I ( $\beta$-GS-I), $\beta$-galactosidase-II ( $\beta$-GS-II ) and $\beta$-galactosidase-III ( $\beta$-GS-III ) respectively. 


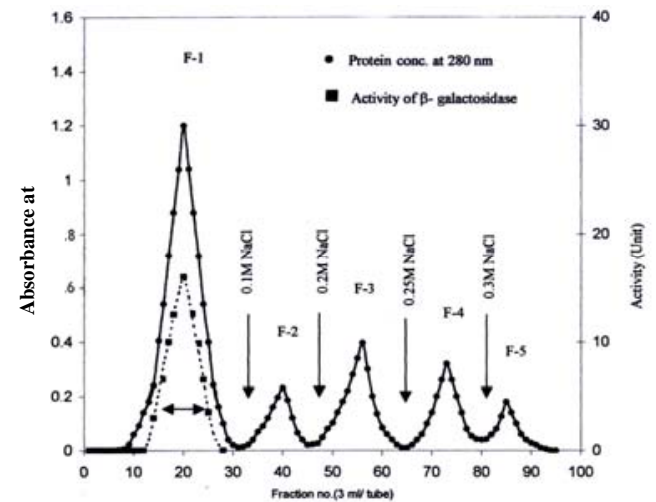

Fig.1 lon-exchange chromatography of crude enzyme extract on DEAE-cellulose. Enzyme extract (360mg) was applied to the column prewashed with $50 \mathrm{mM}$ phosphate buffer, $\mathrm{pH} 7.4$ at $4^{\circ} \mathrm{C}$ and eluted by a stepwise increase of $\mathrm{NaCl}$ in the same buffer.

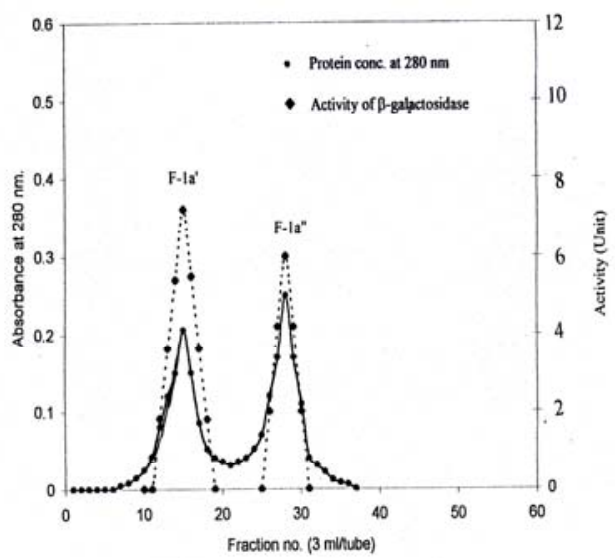

Fig. 3. Polyacrylamide disc gel electrophoretic pattern of the $\beta$ galactosidases fractions on $7.5 \%$ gel at $\mathrm{pH}$ 8.5. $\mathrm{A}=\mathrm{F}-1 \mathrm{a}, \mathrm{B}=\mathrm{F}-$ $1 \mathrm{c}$.

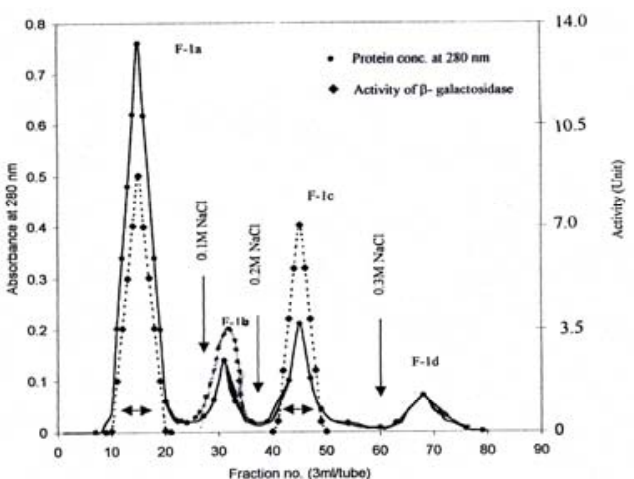

Fig. 2. Ion-exchange chromatography of F-1 fraction on CM-cellulose. Fraction F-1 (27mg) obtained by DEAE-cellulose chromatography was applied to the column prewashed with $0.1 \mathrm{M}$ sodium acetate buffer, $\mathrm{pH} 5.2$ at $4^{\circ} \mathrm{C}$ and eluted by stepwise increase of $\mathrm{NaCl}$ in the same buffer.

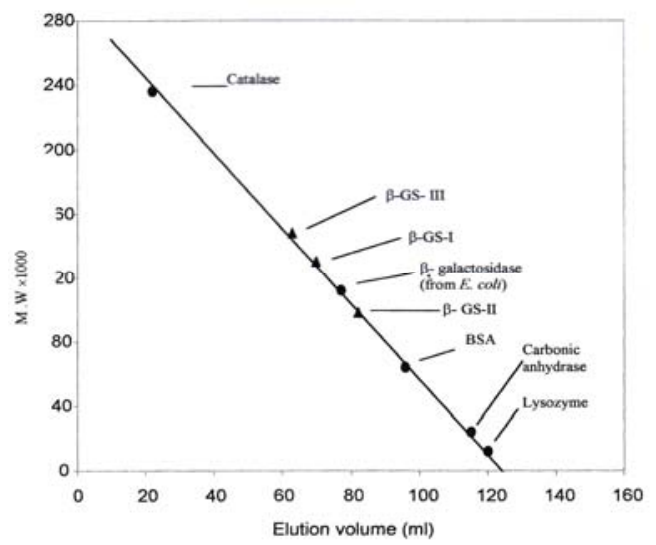

Fig. 4. Gel filtration of F-1a fraction on Sephadex G-75. Fraction, F-1a (14.37mg) obtained by CM-cellulose chromatography was applied to the column pre-equilibrated with $0.1 \mathrm{M}$ sodium acetate buffer , pH 5.2 at $4^{\circ} \mathrm{C}$ and developed with the same buffer

Table 1 summarizes the data pertaining to the purification of betel leaf $\beta$-galactosidases. As presented in the table, the specific activities of $\beta$-galactosidases were increased at each purification steps. Although the yield of enzyme activity w as decreased during the purification steps, but the purification fold of the isomeric forms of $\beta$-galactosidases were increased to about 22 fold. The decrease in yield might be due to denaturation of enzymes during the lengthy purification procedures or for some other reasons.

Characterization of $\beta$-galactosidases: The molecular weight of the enzymes were determined by comparing their elution volume on Sephadex G-150, with those of the marker proteins (catalase, $\beta$-galactosidase, ovalbumin, lysozyme) under same experimental condition. (Fig. 5). The purified enzymes $\beta$-GS-I, $\beta$-GS-II and $\beta$-GS-III in aqueous solution gave absorption maxima around at 276, 274 and $282 \mathrm{~nm}$ and minima around at 241,240 and $244 \mathrm{~nm}$, respectively. The percentage of neutral sugar present in $\beta$-GS-I, $\beta$-GS-II and $\beta$-GS-III were calculated to be $5.2 \%, 4.8 \%$ and $6.9 \%$, respectively. 

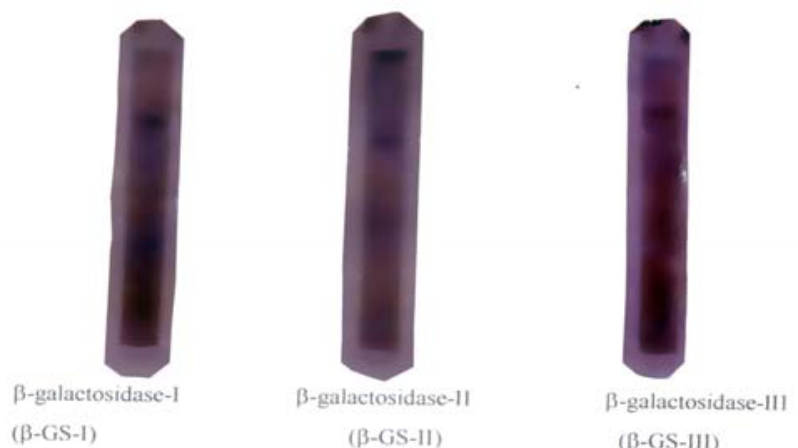

( $\beta$-GS-II)

(B-GS-III)

Fig.5 : Polyacrylamide disc gel electrophoretic pattern of $\beta$-galactosidases fractions. A=F-1a", B=F-1a'
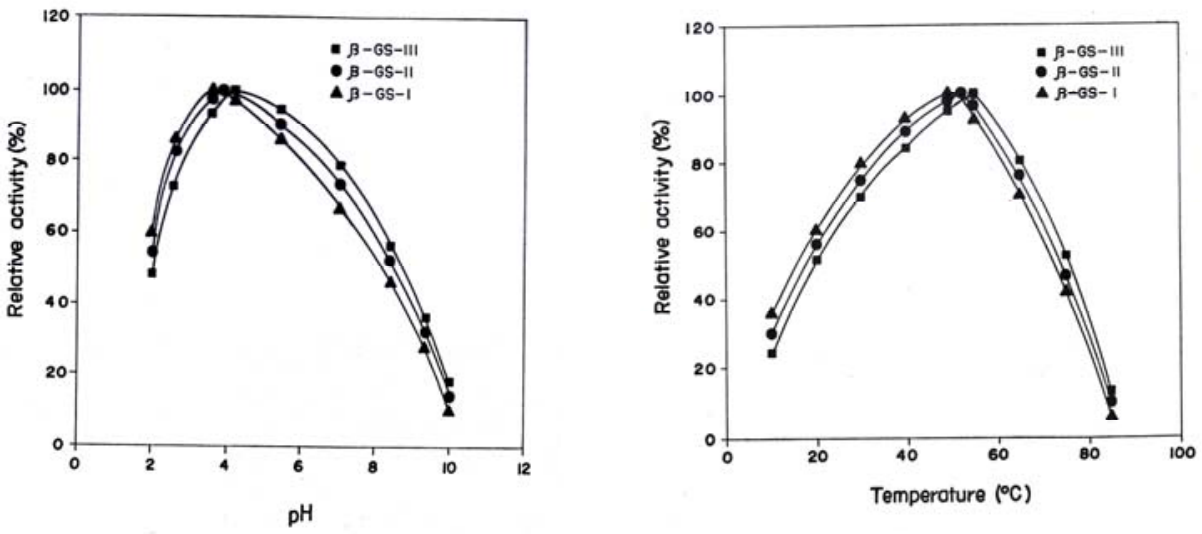

Fig. 6. Effect of $\mathrm{pH}$ on the activities of $\beta$-galactosidase enzymes. The following buffers of $0.1 \mathrm{M}$ were used for the

Fig. 7. Effect of temperature on the activities of $\beta$-galactosidases experimental purpose.
$\mathrm{pH} 2 \rightarrow \mathrm{KCl}-\mathrm{HCl}$
$\mathrm{pH} 3.0-4.0 \rightarrow \mathrm{AcONa}-\mathrm{HCl}$
$\mathrm{pH} 4-5 \rightarrow \mathrm{ACONa-CH} \mathrm{CH}_{3} \mathrm{COOH}$
$\mathrm{pH}$ 6-8 $\rightarrow \mathrm{NaH}_{2} \mathrm{PO}_{4}-\mathrm{Na}_{2} \mathrm{HPO}_{4}$
$\mathrm{pH}$ 8.5-9 $\rightarrow \mathrm{Na}_{2} \mathrm{~B}_{4} \mathrm{O}_{7}-\mathrm{HCl}$
pH $9.5-10 \rightarrow \mathrm{Na}_{2} \mathrm{~B}_{4} \mathrm{O}_{7}-\mathrm{Na}_{2} \mathrm{CO}_{3}$

As demonstrated in Fig. 6 , the activities of the $\beta$-galactosidases were greatly influenced by $\mathrm{pH}$ changes. The $\beta$-GS-I, $\beta$-GS-II and $\beta$-GS-III gave maximum activities in the $\mathrm{pH}$ ranges of $3.5,3.8$ and 4.2 respectively. It can be seen from the $\mathrm{pH}$ activity relationship curve that the enzymes are more stable in the acidic $\mathrm{pH}$ than the alkaline $\mathrm{pH}$ and the enzymes are of acidic type. The activities of betel leaf $\beta$-galactosidases were determined with incubation at various temperatures $\left(10-85^{\circ} \mathrm{C}\right)$ and the results obtained are presented in Fig. 7. As shown in the figure, the activities of the $\beta$-galactosidases were increased gradually with the increase of temperature and the maximum activities were observed at 53,51 and $56^{\circ} \mathrm{C}$ for $\beta$-GS-I, $\beta$-GS-II and $\beta$-GS-III respectively. With further rise of temperature, the activities were decreased abruptly and more than $90 \%$ activities were destroyed at or above $80^{\circ} \mathrm{C}$. 
Table1. Summery of data on course of purification of $\beta$-galactosidases.

\begin{tabular}{|c|c|c|c|c|c|c|c|}
\hline \multicolumn{3}{|c|}{ Steps of purification } & $\begin{array}{l}\text { Total Protein } \\
\quad(\mathrm{mg})\end{array}$ & $\begin{array}{l}\text { Total Activity } \\
\quad \text { (unit) }\end{array}$ & $\begin{array}{l}\text { Specific Activity } \\
\text { (unit/mg) }\end{array}$ & Yield (\%) & Purification fold \\
\hline \multirow{2}{*}{\multicolumn{3}{|c|}{$\begin{array}{l}\text { Crude extract } \\
\text { DEAE-cellulose fraction }\end{array}$}} & 360 & 432 & 1.2 & 100 & 1.00 \\
\hline & & & 27 & 288 & 9.00 & 66.66 & 7.50 \\
\hline \multirow{2}{*}{\multicolumn{2}{|c|}{ CM-cellulose Fraction }} & F-1a & 14.37 & 175 & 12.10 & 40.50 & 10.08 \\
\hline & & $\mathrm{F}-1 \mathrm{C}$ & 11.50 & 70 & 6.08 & 16.20 & 5.06 \\
\hline \multirow{2}{*}{\multicolumn{2}{|c|}{ Gel filtration on Sephadex G-75 }} & F-1a' & 7.0 & 88 & 12.50 & 20.37 & 10.41 \\
\hline & & F-1a" & 6.5 & 52 & 8.00 & 12.03 & 6.66 \\
\hline \multirow{2}{*}{\multicolumn{2}{|c|}{ Chemicals (conc.) }} & \multicolumn{6}{|c|}{ Relative Activities (\%) } \\
\hline & & \multicolumn{2}{|r|}{$\beta$-GS-III } & \multicolumn{2}{|c|}{$\beta$-GS-I } & \\
\hline \multirow{8}{*}{$\operatorname{EDTA}(\mathrm{M})$} & 0.000 & & 100.0 & & 100.0 & \multicolumn{2}{|r|}{100.0} \\
\hline & 0.001 & & 72.3 & & 62.34 & \multicolumn{2}{|r|}{52.45} \\
\hline & 0.002 & & 63.1 & & 55.56 & \multicolumn{2}{|r|}{51.3} \\
\hline & 0.005 & & 50.87 & & 49.4 & \multicolumn{2}{|r|}{44.2} \\
\hline & 0.010 & & 34.5 & & 31.15 & \multicolumn{2}{|r|}{28.54} \\
\hline & 0.100 & & 16.62 & & 14.00 & \multicolumn{2}{|r|}{12.12} \\
\hline & 0.200 & & 5.1 & & 4.12 & \multicolumn{2}{|r|}{2.43} \\
\hline & 0.500 & & 0.00 & & 0.00 & \multicolumn{2}{|r|}{0.00} \\
\hline \multirow{6}{*}{ Urea (M) } & 0 & & 100.0 & & 100.0 & \multicolumn{2}{|r|}{100.0} \\
\hline & 1 & & 93.24 & & 86.12 & \multicolumn{2}{|r|}{75.45} \\
\hline & 2 & & 74.56 & & 72.4 & \multicolumn{2}{|r|}{55.87} \\
\hline & 4 & & 47.56 & & 43.44 & \multicolumn{2}{|r|}{22.34} \\
\hline & 6 & & 20.43 & & 7.89 & \multicolumn{2}{|r|}{0.00} \\
\hline & 8 & & 0.00 & & 0.00 & \multicolumn{2}{|r|}{0.00} \\
\hline \multirow{6}{*}{ Acetic acid (\%) } & 0.00 & & 100.0 & & 100.0 & \multicolumn{2}{|r|}{100.0} \\
\hline & 2.50 & & 93.34 & & 86.65 & \multicolumn{2}{|r|}{74.56} \\
\hline & 5.00 & & 76.89 & & 67.23 & \multicolumn{2}{|r|}{46.76} \\
\hline & 10.00 & & 44.12 & & 32.87 & \multicolumn{2}{|r|}{18.25} \\
\hline & 20.00 & & 18.2 & & 7.54 & & 0.00 \\
\hline & 30.00 & & 0.00 & & 0.00 & & 0.00 \\
\hline
\end{tabular}

Effect of urea, EDTA and acetic acid: As shown in the Table 2, the activities of $\beta$-galactosidases were found to be decreased remarkably with the increasing concentration of urea. In the presence of $6 \mathrm{M}$ urea the activity of $\beta$-GS-II destroyed completely, while those of $\beta$-GS-I and $\beta$-GS-III were decreased about $92 \%$ and $80 \%$ respectively. The activities of $\beta$-galactosidases gradually decreased with the treatment of higher percentage of acetic acid and the enzymes lost its 100\% activity at 30M concentration. EDTA had profound effect on $\beta$-galactosidases and it was found that the activities of $\beta$-galactosidases were decreased gradually with the treatment of higher concentration of EDTA and more than $95 \%$ activities of the enzymes abolished in the presence of $0.2 \mathrm{M}$ EDTA.

Effect of various metallic salt: Table 3 shows the effect of various metallic salts on the activities of $\beta$ galactosidases. It was evident that the activities of $\beta$-galactosidases were abolished completely in the presence of $\mathrm{Hg}_{2} \mathrm{Cl}_{2}$, suggesting the involvement of $-\mathrm{SH}$ at the active sites. The activities of enzymes were increased in the presence of metallic salts of $\mathrm{Mg}^{2+}$ and $\mathrm{Mn}^{2+}$, while salts of $\mathrm{Cu}^{2+}$ and $\mathrm{Fe}^{2+}$ reduced the activities remarkably. On the other hand, metallic salts of $\mathrm{Zn}^{2+}$ and $\mathrm{Na}^{+}$produced little inhibitory effect on the activities. Further, the activities of the enzymes were gradually increased with the increase in concentration of calcium and in the presence of $0.5 \mathrm{M} \mathrm{Ca}^{2+}$, the activities of $\beta$-GS-I, $\beta$-GS-II and $\beta$-GS-III became about $121 \%, 118 \%$ and $131 \%$ respectively. 
Table 3. Effect of various metallic salts on the activities of $\beta$-galactosidases.

\begin{tabular}{|c|c|c|c|c|}
\hline \multicolumn{2}{|c|}{ Chemicals (M conc.) } & \multicolumn{3}{|c|}{ Activity (\%) } \\
\hline & & $\beta$-GS-I & $\beta$-GS-II & $\beta$-GS-III \\
\hline \multirow[t]{2}{*}{ None } & None & 100 & 100 & 100 \\
\hline & 0.001 & 103.4 & 100.0 & 100.0 \\
\hline \multirow{3}{*}{$\mathrm{CaCl}_{2}$} & 0.005 & 107.8 & 105.5 & 104.3 \\
\hline & 0.1 & 119.8 & 113.2 & 112.5 \\
\hline & 0.5 & 130.6 & 121.5 & 117.9 \\
\hline \multirow{2}{*}{$\mathrm{MgCl}_{2}$} & 0.001 & 106.0 & 104.3 & 102.5 \\
\hline & 0.002 & 107.4 & 105.5 & 103.8 \\
\hline \multirow{2}{*}{$\mathrm{ZnCl}_{2}$} & 0.001 & 98.5 & 95.5 & 92.9 \\
\hline & 0.002 & 93.3 & 91.1 & 90.1 \\
\hline \multirow{2}{*}{$\mathrm{CuCl}_{2}$} & 0.001 & 73.4 & 71.1 & 66.3 \\
\hline & 0.002 & 59.6 & 56.5 & 49.9 \\
\hline \multirow{2}{*}{$\mathrm{MnCl}_{2}$} & 0.001 & 112.3 & 110.7 & 106.5 \\
\hline & 0.002 & 123.4 & 117.5 & 111.6 \\
\hline $\mathrm{HgCl}_{2}$ & 0.001 & 0 & 0 & 0 \\
\hline \multirow{3}{*}{$\mathrm{KCl}$} & 0.001 & 100 & 97.8 & 96.8 \\
\hline & 0.002 & 100 & 95.6 & 94.9 \\
\hline & 1 & 93.24 & 86.1 & 75.5 \\
\hline \multirow[t]{2}{*}{ Urea } & 4 & 47.6 & 43.4 & 22.3 \\
\hline & 6 & 20.4 & 7.9 & 0 \\
\hline
\end{tabular}

\section{Discussion}

There is increasing evidence that fruit ripening is accomplished by a decrease in galactose content of cell walls and that this loss of galactose represents a separate process in the degradation of the cell walls responsible for fruit ripening (Ranwala et al. 1992). Substantial decline in the cell wall galactose have been reported for ripening apples (Knee 1973), the straw berries (Knee et al. 1977) and tomatoes (Wallner and Bloom 1977). It was found in our laboratory that the betle leaves at mature stage contained significant amount of reducing sugar as well as $\beta$-galactosidases. All the three $\beta$-galactosidases were glycoprotein in nature as they gave pinkish red colour with phenol sulphuric acid. Although all the three $\beta$-galactosidases are pentamer and the subunits are held together by disulphide bonds but the enzymes are quite different from each other in their mobility on polyacrylamide gel ( Fig. 6), pH maxima (Fig. 7), temperature optima (Fig. 8), neutral sugar content etc. Similar subunit structure of $\beta$-galactosidases were also reported by Whitaker (1994).

The activities of all the three enzymes were abolished in presence of EDTA, but increased in the presence of $\mathrm{Ca}^{2+}, \mathrm{Mg}^{2+}$ and $\mathrm{Mn}^{2+}$, suggesting the importance of specific metal ions in the active sites of the enzymes. Further, the activities of the enzymes were also abolished completely in the presence of $\mathrm{HgCl}_{2}$, suggesting the involvement of $-\mathrm{SH}$ group, which may be located at or near the active site.

\section{Conclusions}

The results of the present study confirm that the activity of $\beta$-galactosidase in mature betel leaves is not due to a single $\beta$-galactosidase, but to three isomeric forms which can be purified by a combination of ionexchange chromatography on DEAE- and CM-cellulose followed by gel filtration on Sephadex G-75. We also characterized and analyzed physico-chemical properties of these enzymes. As far we know, this is the first report of purification and characterization of $\beta$-galactosidase from betel leaves. 


\section{References}

Andrews P. 1964. Estimation of the Molecular Weights of Proteins by Sephadex Gel-Filtration. Biochem J 91, 222-233.

Artolozaga MJ, Jonas R, Schneider AL, Furlan SA, Carvalho-Jonas MF. 1998. One step partial purification of $\beta$-galactosidase from Kluyveromyces marxianus CDB 002 using STREAMLINE-DEAE. Bioseparation 7(3), 137-143. http://dx.doi:10.1023/A: 1008082420399

Asraf SS and Gunasekaran P. 2010. Current trends of ß-galactosidase research and application. In: Mendez-Vilas A (ed) Current Research, Technology and education topics in Applird Microbiology and Nicrobial Biotechnology. 880-890pp. Formatex, Spain.

Bartley IM. 1974. $\beta$-Galactosidase activity in ripening apples. Phytochem 13, 2107-2111. http://dx.doi:10.1016/0031-9422(74)85011-9

Burns JK. 1990. $\alpha$ and $\beta$-Galactosidase activities in juice vesicles of stored Valencia oranges. Phytochem 29, 2425-2429. http://dx.doi:10.1016/0031-9422(90)85160-H

Corchete MP, Guerra H. 1987. $\alpha$ and $\beta$-Galactosidase activities in protein bodies and cell walls of lentil seed cotyledons. Phytochem 26, 927-932 . http://dx.doi:10.1016/S0031-9422(00)82319-5

CSIR (Council of Scientific and Industrial Research, New Delhi). 1969. The Wealth of India, 8: 84-94. CSIR, New Delhi.

Dagbagli S, Goksungur Y. 2008. Optimization of $\beta$-galactosidase production using Kluyveromyces lactis NRRL Y-8279 by response surface methodology. Electronic J Biotech 11(4), 1-12. http://dx.doi:10.2225/vol11-issue4-fulltext-12

Dey PM, Campillo ED. 1984. Biochemistry of the multiple forms of glycosidases in plants. Adv Enzymol 56, 146-249

Dubois M, Gilles KA, Hamilton JK, Rebers PA, Smith F. 1956. Colorimetric method for determination of sugars and related substances. Anal Chem 28, 350-356. http://dx.doi:10.1021/ac60111a017

Gross KC, Watada AE, Kang MS, Kim SD, Kim KS, Lee SW. 1986. Biochemical changes associated with the ripening of hot pepper fruit. Physiol Plant 66, 31-36. http://dx.doi:10.1111/j.1399-3054.1986.tb01227.x

Guha P. 2006. Betel Leaf: The Neglected Green Gold of India. J Hum Ecol 19(2), 87-93. http://dx.doi:10.1016/0031-9422(73)80365-6

Knee, M. 1973. Polysaccharide changes in cell walls of ripening apples. Phytochem 12, 1543-1549.

Knee, M._Sargent, J.A. and Osborne, D.J 1977. Cell wall metabolism in developing strawberry fruits. J Exp Bot 28, 377-396. http://dx.doi:10.1093/jxb/28.2.377

Konno H, Yamasaki Y, Katoh K. 1986. Characteristics of $\beta$-Galactosidase purified from cell suspension cultures of carrot. Physiol Plant 68, 46-52. http://dx.doi:10.1111/j.1399-3054.1986.tb06594.x

Lazan H, Ali ZM, Soh J, Talkah Z. 1993. The biochemical basis of differential ripening in mango. Acta Hort 341, 500-509.

Lowry OH, Rosebrough NJ, Farr AL, Randall RJ. 1951. Protein measurement with the Folin Phenol Reagent. J Biol Chem 193, 265-275.

Miller GL. 1972. Use of dinitrosalicyclic reagent for the determination of reducing sugar. Anal Chem 31, 426-428. http://dx.doi:10.1021/ac60147a030

Ornstein, L. 1964. Disc electrophoresis - I. Background and theory. 321-349p. In Whipple HE (ed.) Gel electrophoresis. Ann NY Acad Sci 121.

Pressey R. 1983. $\beta$-Galactosidases in ripening tomatoes. Plant Physiol 71, 132-135. http://dx.doi:10.1104/pp.71.1.132 PMid:16662771 PMCid:1065999

Ranwala AP, Suematsu C, Masuda H. 1992. The role of $\beta$-galactosidases in the modification of cell wall components during muskmelon fruit ripening. Plant Physiol 100, 1318-1325, http://dx.doi:10.1104/pp.100.3.1318 PMid:16653123 PMCid:1075784

Santos A, Ladero M, Garcia-Ochoa F. 1998. Kinetic modeling of lactose hydrolysis by $\beta$-galactosidase from Kluyveromyces fragilis. Enzy Micribiol Tech 22(7), 558-567. http://dx.doi:10.1016/S0141-0229(97)00236-6

Shaikh SA, Khire JM, Kham MI. 1997. Production of $\beta$-galactosidase from thermophilic fungus Rhizomucor sp. J Indust Microbiol Biotechnol 19(4), 239-245. http://dx.doi:10.1038/sj.jim.2900452

Sharma ML, Rawat AKS, Khanna RK, Chowdhury AR, Raina RM. 1996. Flavour characteristics of betel leaves. Euro cosmetics 5, 2224.

Wallner SJ, Bloom HL. 1977. Characteristics of tomato cell wall degradation in vitro: Implications for the study of fruit softening enzymes. Plant Physiol 60, 207-210. http://dx.doi:10.1104/pp.60.2.207 PMid:16660060 PMCid:542580

Weber K, Osborn M. 1969. The reliability of molecular weight deermination by dodecyl sulphate polyacrylamide gel electrophoresis. J Biol Chem 244, 4406-4412. PMid:5806584

Whitaker JR. 1994. Principles of Enzymology for the for the Food Sciences (2nded.). Marcel Dekkar Inc, New York, 511pp 